\title{
Penerapan Model Pembelajaran Artikulasi dengan Media Gambar Guna Meningkatkan Prestasi Belajar IPA
}

\author{
I Desak Made Yastiari
}

SD Negeri 3 Tulikup

\section{A R T I C L E I N F O Article history: \\ Received 18 August 2019 Received in revised form 19 September 2019 Accepted 25 October 2019 Available online 30 November 2019}

Kata Kunci:

Model Pembelajaran Artikulasi, Media Gambar Prestasi Belajar

Keywords: Articulation Learning Model, Image Media, Learning Achievement

\begin{abstract}
A B S T R A K
Penelitian ini dilaksanakan di SD Negeri 3 Tulikup di kelas $V$ yang kemampuan siswanya untuk materi pelajaran IPA masih tergolong sangat rendah. Tujuan penulisan penelitian tindakan kelas ini adalah untuk meningkatkan prestasi belajar IPA siswa kelas V SD Negeri 3 Tulikup pada semester I tahun pelajaran 2017/2018 melalui penerapan model pembelajaran Artikulasi dengan media gambar. Metode pengumpulan datanya adalah tes prestasi belajar. Metode analisis datanya adalah deskriptif kuantitatif. Hasil yang diperoleh dari penelitian ini adalah penerapan model pembelajaran Artikulasi dengan media gambar dapat meningkatkan prestasi belajar IPA siswa kelas V. Ini terbukti dari hasil yang diperoleh pada awalnya dengan nilai rata-rata 59,68 , pada siklus I menjadi 69,37 dan pada siklus II mengalami peningkatan yang cukup signifikan yaitu menjadi 78,75 . Ketuntasan belajar meningkat dari $43,75 \%$ pada awal pembelajaran menjadi $68,75 \%$ pada siklus I dan $100 \%$ pada siklus II. Kesimpulan yang diperoleh dari penelitian ini adalah penerapan model pembelajaran Artikulasi dengan media gambar dapat meningkatkan prestasi belajar IPA siswa kelas V SD Negeri 3 Tulikup pada semester I tahun pelajaran $2017 / 2018$.
\end{abstract}

\section{A B S T R A C T}

This research was conducted in Tulikup State Elementary School 3 in class $V$ where the ability of students for science subject matter was still very low. The purpose of writing this class action research is to improve the science learning achievement of fifth grade students of SD Negeri 3 Tulikup in the first semester of the 2017/2018 academic year through the application of the Articulation learning model with image media. The data collection method is a learning achievement test. The data analysis method is quantitative descriptive. The results obtained from this study are the application of the Articulation learning model with media images can improve the learning achievement of $\mathrm{V}$ grade students. This is evident from the results obtained initially with an average value of 59.68, in the first cycle to 69.37 and in the cycle II experienced a significant increase to 78.75. Mastery learning increased from $43.75 \%$ at the beginning of learning to $68.75 \%$ in the first cycle and $100 \%$ in the second cycle. The conclusion obtained from this study is the application of the Articulation learning model with image media can improve the science learning achievement of fifth grade students of SD Negeri 3 Tulikup in the first semester of the academic year 2017/2018.

\footnotetext{
${ }^{1}$ Corresponding author.

E-mail addresses: desakmadeyastiari01@Gmail.com (I Desak Made Yastiari)
} 


\section{Pendahuluan}

Pendidikan juga merupakan kegiatan yang universal dalam kehidupan manusia, dengan pendidikan manusia berusaha mengembangkan potensi yang dimilikinya, mengubah tingkah laku ke arah yang lebih baik. Tujuan pendidikan nasional adalah mengupayakan perluasan dan pemerataan kesempatan memperoleh pendidikan yang bermutu tinggi bagi seluruh rakyat Indonesia sendiri secara optimal disertai dengan hak dukungan dan lindungan sesuai dengan potensinya. Sebagai perwujudan pencapaian tujuan tersebut maka belajar merupakan suatu proses aktif memerlukan dorongan dan bimbingan ke arah tercapainya tujuan yang dikehendaki [1]. Salah satu permasalahan mutu pendidikan di Indonesia adalah rendahnya mutu proses pembelajaran seperti metode mengajar guru yang tidak tepat, kurikulum, manajemen sekolah yang tidak efektif dan kurangnya motivasi siswa dalam belajar. Hasil survei PISA (Programme for International Student Assesment) terakhir pada tahun 2012 menunjukkan bahwa bidang sains Indonesia menduduki peringkat 64 dari 65 negara. Ditemukan bahwa negara dengan siswa yang memiliki keyakinan akan kemampuannya akan meningkatkan prestasi mereka. Selain itu semakin mereka menikmati belajar, semakin tinggi prestasi belajar mereka [2]. Hal ini menujukkan bahwa motivasi mempunyai peranan yang cukup besar di dalam upaya belajar.

Berbagai laporan mengungkapkan bahwa prestasi belajar (academic achievement) peserta didik Indonesia kurang optimal. Laporan-laporan tersebut antara lain oleh The International Association for the Evaluation of Educational Achievement (IEA) Tahun 2011. IEA merupakan salah satu lembaga Internasional independen, melakukan penelitian dan studi dalam skala besar mengukur perbandingan prestasi dan aspek-aspek lain pendidikan di 64 negara di dunia sebagai peserta. Dari hasil pengukuran kemampuan bidang IPA dan matematika Internasional, pelajar SMP Indonesia berada pada urutan 38 dari 39 negara yang disurvei (IEA, 2011), sedangkan hasil pengukuran Trends in International Mathematics and Science Study (TIMSS) Tahun 2011, kemampuan matematika pelajar SMP Indonesia juga berada pada urutan 34 dari 38 negara, sedangkan kemampuan pelajar Indonesia pada bidang IPA berada di urutan ke 32 dari 38 negara yang disurvei (TIMSS, 2011). Kualitas pendidikan Indonesia seperti yang dilaporkan oleh The International Association for the Evaluation of Educational Achievement (IEA) dan Trends in International Mathematics and Science Study (TIMSS), perlu dicermati dan ditindaklanjuti. Berdasarkan pralapangan diketahui bahwa SMA Negeri 1 Lawang Kabupaten Malang: skor rata-rata nilai Ujian Nasional (UN) lima mata pelajaran perolehan nilai dengan rentang skor 8.6 sampai dengan 10 hanya diperoleh oleh 26 dari 412 peserta didik yang ikut dan dinyatkan lulus UN 2012. Hal ini berarti bahwa hanya 6.28\% lulus dengan prestasi belajar yang baik, sementara 274 peserta didik (66.52\%) berada pada posisi sedang dan 112 peserta didik (27.20\%) berada pada posisi rendah. Lebih lanjut, penelusuran literatur, cukup banyak penelitian yang mencoba mengungkapkan kasus menyontek. Penelitian Rittman (1996); Bogle (2000); dan Turrens, dkk., (2002) mencoba mengungkap perilaku menyontek dengan angket sebagai alat instrumenasinya. Penelitian Thorpe, dkk., (1999) perilaku menyontek terjadi karena nilai pelajar rendah karena kemampuannya memang rendah, ia memiliki hasrat untuk mendapatkan nilai belajar yang lebih tinggi (Yuzarion, 2017).

Kualitas pendidikan berkaitan dengan kualitas siswa karena titik pusat dalam proses belajar mengajar adalah siswa. Siswa diharapkan dapat menimba ilmu dan wawasan yang sebanyakbanyaknya dengan belajar. Belajar adalah suatu proses di mana di dalamnya terjadi suatu interaksi antara seorang siswa dengan lingkungannya yang mengakibatkan adanya perubahan tingkah laku yang akan memberikan suatu pengalaman, baik bersifat pengetahuan, sikap dan keterampilan. Cara untuk mengukur kemampuan, pengetahuan dan pemahaman siswa tentang suatu mata pelajaran di sekolah yaitu dengan melihat prestasi belajar siswa. Dalam rangka meningkatkan kualitas pendidikan, masalah yang harus mendapat perhatian adalah cara belajar siswa. Mengingat keberhasilan pencapaian tujuan belajar ditentukan oleh faktor cara belajar yang juga sangat menentukan berhasil tidaknya kegiatan pendidikan. Setiap siswa memiliki perbedaan cara belajar antara yang satu dengan yang lainnya dalam aspek fisik, pola berpikir, dan cara merespon atau mempelajari sesuatu yang baru (Ernita, 2016).

Untuk mendukung siswa termotivasi dalam belajar maka harus didukung dengan suasana pembelajaran yang kondusif. Kondisi belajar mengajar yang efektif adalah adanya minat perhatian siswa dalam belajar [3]. Dalam interaksi belajar mengajar terdapat berbagai macam model pembelajaran yang bertujuan agar proses belajar mengajar dapat berjalan baik. Hal ini juga bertujuan untuk menciptakan proses belajar mengajar aktif srta memungkinkan timbulnya sikap ketertarikan siswa terhadap proses pembelajaran sehingga apabila siswa memiliki ketertarikan dengan model suatu pembelajaran, maka akan menjamin siswa dapat menyerap materi yang diajarkan secara maksimal. Salah satu model pembelajaran yang dapat menciptakan kegiatan proses belajar mengajar menyenangkan dan menarik yaitu model pembelajaran kooperatif tipe artikulasi. Model pembelajaran kooperatif tipe artikulasi merupakan model pembelajaran yang prosesnya seperti pesan berantai, artinya seorang siswa wajib 
meneruskan menjelaskan pada siswa lain sebagai pasangannya materi yang sudah dijelaskan oleh guru, kemudian siswa yang menyimak berganti peran menjelaskan kepada pasangannya [4]. Penelitian terkait model pembelajaran artikulasi telah banyak dilakukan, diantaranya yaitu model pembelajaran artikulasi yang dipadukan dengan metode mnemonik berpengaruh secara signifikan terhadap hasil belajar IPA (Wepe, 2016).

Pendidikan merupakan suatu proses yang mencakup tiga dimensi, individu, masyarakat atau komunitas nasional dari individu tersebut, dan seluruh kandungan realitas, baik material maupun spiritual yang memainkan peranan dalam menentukan sifat, nasib, bentuk manusia maupun masyarakat.

Pendidikan lebih dari sekedar pengajaran, yang dapat dikatakan sebagai suatu proses transfer ilmu, transformasi nilai, dan pembentukan kepribadian dengan segala aspek yang dicakupnya. Dengan demikian pengajaran lebih berorientasi pada pembentukan spesialis atau bidangbidang tertentu, oleh karena itu perhatian dan minatnya lebih bersifat teknis. Pendidikan merupakan suatu proses yang diperlukan untuk mendapatkan keseimbangan dan kesempurnaan dalam perkembangan individu maupun masyarakat. Penekanan pendidikan dibanding dengan pengajaran terletak pada pembentukan kesadaran dan kepribadian individu atau masyarakat di samping transfer ilmu dan keahlian. Dengan proses semacam ini suatu bangsa atau negara dapat mewariskan nilai-nilai keagamaan, kebudayaan, pemikiran dan keahlian kepada generasi berikutnya, sehingga mereka betul-betul siap menyongsong masa depan kehidupan bangsa dan negara yang lebih cerah. Pendidikan juga merupakan sebuah aktifitas yang memiliki maksud atau tujuan tertentu yang diarahkan untuk mengembangkan potensi yang dimiliki manusia baik sebagai manusia ataupun sebagai masyarakat dengan sepenuhnya (Nurkholis, 2013).

Teori pendidikan merupakan landasan dan pijakan awal dalam pengembangan praktik pendidikan, misalnya pengembangan kurikulum, manajemen sekolah dan proses belajarmengajar. Kurikulum dan pembelajaran memiliki keterkaitan dengan teori pendidikan atau dalam penyusunan suatu kurikulum dan rencana pembelajaran ini mengacu pada teori pendidikan. Berbagai teori yang dikembangkan saat ini telah mewarnai proses dan praktik pendidikan. Sumbangsih para tokoh dalam menciptakan teori telah memberikan perkembangan dan kemajuan dalam proses pendidikan. Lahirnya teori dalam bidang pendidikan memberikan warna baru terhadap sistem pendidikan, proses belajar mengajar, manajemen sekolah dan metode pembelajaran. Adanya pergeseran metode dan pola didik pengajar terhadap peserta didik merupakan proses dari pelaksanaan teori dalam bidang pendidikan. Sebagai contoh berkembangnya pola pendidikan active learning dimana proses pembelajaran tidak hanya terpusat pada pengajar akan tetapi peserta didik mempunyai peranan sangat menentukan hasil belajar. Hal ini dipelopori oleh teori yang berkembang yaitu teori behaviorisme dimana setiap manusia mempunyai kemampuan untuk berfikir dan melakukan setiap aktifitas dalam proses belajar. Sehingga dengan teori ini setiap peserta didik diberikan ruang kebebasan untuk melakukan kegiatan yang disesuaikan dengan kemampuan peserta didik, tugas pengajar bersifat pengarah dan fasilitator, hal ini memungkinkan terbentuknya rasa percaya diri serta kemampuan peserta didik untuk menciptakan hal-hal yang inovatif dan kreatif.

Teori pendidikan yang dikembangkan dunia Barat telah memberikan sumbangsih pada perkembangan ilmu pengetahuan di dunia, dalam berbagai praktek pola pendidikan yang bersumber dari Barat berorientasi pada sudut material dan menghasilkan keuntungan kepada manusia secara materi. Karena bersandar pada materi maka sesuatu yang tidak empiris dianggap mitos. Hal ini menyebabkan pola pikir manusia cenderung matrealistis, logis dan hanya berorientasi kepada akal (Sholichah, 2018).

Permendiknas RI No. 41 tahun 2007 menyebutkan bahwa proses pembelajaran pada setiap satuan pendidikan dasar dan menengah harus interaktif, inspiratif, menyenangkan, menantang, dan memotivasi peserta didik untuk berpartisipasi aktif serta memberikan ruang yang cukup bagi prakarsa, kreativitas dan kemandirian sesuai dengan bakat, minat, dan perkembangan fisik serta psikologis peserta didik. Karena itu orientasi pembelajaran harus ditekankan kepada peserta didik sebagai subjek, yang harus aktif dan kreatif melaksanakan proses pembelajaran dengan arahan dan bantuan dari guru. Guru dalam hal ini harus betul-betul aktif memerankan dirinya sebagai fasilitator, motivator dan lain-lain untuk peningkatan prestasi dan mampu mensyukuri karunia Tuhan.

Hal yang tidak kalah pentingnya adalah pemahaman guru tentang proses pembelajaran dapat berlangsung aktif, kreatif dan amenarik. Hal ini akan bisa terjadi bila dalam diri siswa tumbuh rasa ingin tahu, mencari jawaban atas pertanyaan, memperluas dan memperdalam pemahaman dengan menggunakan metode yang efektif. Rasa ingin tahu siswa muncul dan terlihat ketika sudah mulai mengajukan pertanyaan-pertanyaan. Pertanyaan inilah nantinya yang akan menjadi bahan pembelajaran untuk dicari jawabannya bersama-sama antara guru dan siswa. Agar mampu menjawab semua pertanyaan yang dilontarkan siswa dan memberikan dampak yang baik terhadap kelangsungan pembelajaran mereka, seorang guru harus benar-benar memiliki pengetahuan yang mendalam tentang materi yang diajarkan sehingga dia layak disebut seorang guru yang kompeten. 
Sekolah Dasar sebagai gerbang awal peserta didik mengenyam pendidikan formal harus dikemas sedemikian rupa agar perkembangan kemampuan anak sejalan dengan kondisi jaman. Untuk itulah pembaharuan dari segi Kurikulum pendidikan selalu dilakukan demi meluruskan dan memuluskan jalan bagi peserta didik untuk menemukan jati diri mereka, memperoleh bekal pengetahuan hidup yang relevan untuk dimanfaatkan menghadapi arus globalisasi yang ditandai dengan pesatnya perkembangan terknologi informasi.

Pengembangan kurikulum Sekolah Dasar dalam (Depdiknas: 2009) dikembangkan berdasarkan prinsip-prinsip sebagai berikut: (1) berpusat pada potensi, perkembangan, kebutuhan, dan kepentingan peserta didik dan lingkungannya; (2) beragam dan terpadu; (3) tanggap terhadap perkembangan ilmu pengetahuan, teknologi dan seni; (4) relevan dengan kebutuhan kehidupan; (5) menyeluruh dan berkesinambungan; (6) belajar sepanjang

Dari pernyataan tersebut tersirat pesan bahwa pendidikan perlu mendapatkan perhatian yang serius. Melihat begitu pentingnya peran pendidikan, maka pemerintah merumuskan fungsi dan tujuan pendidikan nasional dalam Undang-undang Sistem Pendidikan Nasional. Dalam Undang-undang Sistem Pendidikan Nasional No. 20 tahun 2003 pasal 1 ayat 1 disebutkan bahwa pendidikan adalah usaha sadar dan terencana untuk mewujudkan suasana belajar dan proses pembelajaran agar siswa secara aktif mengembangkan potensi dirinya untuk memiliki kekuatan spiritual keagamaan, pengendalian diri, kepribadian, kecerdasan, akhlak mulia, serta keterampilan yang diperlukan dirinya, masyarakat, bangsa, dan negara.

Keberhasilan proses pembelajaran lebih banyak ditentukan oleh kemampuan guru dalam mengelola proses pembelajaran tersebut. Kadang ada guru yang disebut pintar tetapi lemah dalam menyampaikan pengetahuan dan pemahaman yang ada dalam dirinya maka tentu proses pembelajaran tidak akan berhasil dengan baik. Kadang ada guru yang disebut tidak terlalu pintar tetapi dalam menyampaikan dan mengelola pembelajaran lebih kreatif dan memahami cara penyampaiannya bisa jadi menyebabkan proses pembelajaran akan berhasil dengan baik. Di antara keduanya tentu yang paling sesuai adalah memiliki kemampuan profesionalisme keguruan dan mampu menyampaikan dengan baik demi terciptanya proses dan tujuan pembelajaran yang diharapkan untuk mampu meningkatkan ketakwaan terhadap Tuhan Yang Maha Esa.

Sehubungan dengan proses pembelajaran yang berlangsung di SD Negeri 3 Tulikup dari hasil pengumpulan data awal didapat nilai rata-rata siswa kelas $\mathrm{V}$ pada mata pelajaran IPA khususnya dalam materi IPA baru mencapai 59,68 dengan ketuntasan belajar hanya mencapai 43,75\%. Hasil tersebut tentu tidak sesuai dengan harapan keberhasilan pendidikan yang ditetapkan yaitu 70,00. Tentang pelajaran yang disampaikan, jika pelajaran sempat diterima peserta didik dan belum berhasil, boleh jadi penyebabnya dikarenakan keterbatasan kemauan guru dalam menerapkan semua keilmuan yang dikuasai demi pencapaian hasil maksimal dalam pembelajaran

Selanjutnya peneliti/guru melaksanakan perbaikan pembelajaran dengan menerapkan model pembelajaran Artikulasi dengan media gambar supaya dapat meningkatkan prestasi belajar IPA siswa khususnya siswa kelas V di SD Negeri 3 Tulikup.

Menurut Mustain (2010: 30) artikulasi adalah apa yang kita definisikan sebagai struktur-struktur dalam otak yang melibatkan kemampuan bicara (area kemampuan bicara), membaca atau pemprosesan kata lainnya dan area gerak tambahan (menulis, membuat sketsa, dan gerak-gerak ekspresif lainnya). Artinya, artikulasi merujuk kepada apa-apa saja yang berkaitan dengan berbicara atau melakukan sesuatu akibat dari pemprosesan hasil kerja otak. Penerapan model artikulasi dalam pembelajaran juga melibatkan kemampuan berbicara serta gerak ekspresi akibat kegiatan berpikir siswa. Model artikulasi berbentuk kelompok berpasangan, di mana salah satu siswa menyampaikan materi yang baru diterima kepada pasangannya kemudian bergantian, presentasi di depan kelas perihal hasil diskusinya dan guru membimbing siswa untuk memberikan kesimpulan.

Huda (2013: 269) menjelaskan bahwa pembelajaran artikulasi merupakan model pembelajaran yang menuntut siswa aktif dalam pembelajaran. Pada pembelajaran ini, siswa dibagi ke dalam kelompokkelompok kecil yang masing-masing anggotanya bertugas mewawancarai teman kelompoknya tentang materi yang baru dibahas. Skill pemahaman sangat diperlukan dalam model pembelajaran ini.

Model pembelajaran artikulasi merupakan model pembelajaran yang menekankan pada konsep siswa aktif. Siswa dibagi kedalam kelompok kecil berpasangan, satu siswa bertugas mewawancarai siswa lain mengenai materi yang disampaikan oleh guru, hal ini dilakukan bergantian. Kemudian tiap kelompok menyampaikan hasil kegiatan kelompok kepada kelompok yang lain.

Model artikulasi adalah model pembelajaran yang menekankan pada aspek komunikasi kelompok berpasangan dengan teman sebagai sumber belajar. Pada model ini terjadi proses interaksi antar anggota, salah satu anggota menjadi narasumber sementara yang lain merekam informasi, dan selanjutnya 
bergantian. Kemudian hasil belajar tersebut didiskusikan dengan kelompok lain sehingga kelompok lain juga mendapat informasi serupa. Jadi, pada model ini terjadi pembelajaran dari siswa untuk siswa.

\section{Metode}

Penelitian Tindakan Kelas (PTK) ini dilaksanakan di SD Negeri 3 Tulikup yang berlokasi di Jalan Raya Tulikup, Br. Bayad, Tulikup, Tegalalang, Kabupaten Gianyar.

Penelitian ini merupakan penelitian tindakan kelas yang akan dilaksanakan dalam dua siklus. Jika pada siklus pertama prestasi belajar IPA siswa belum memenuhi kriteria keberhasilan, maka berdasarkan hasil refleksi akan dilakukan perbaikan pada siklus selanjutnya. Secara operasional prosedur dasar pengembangan tindakan yang akan dilakukan dapat dijabarkan sebagai berikut.

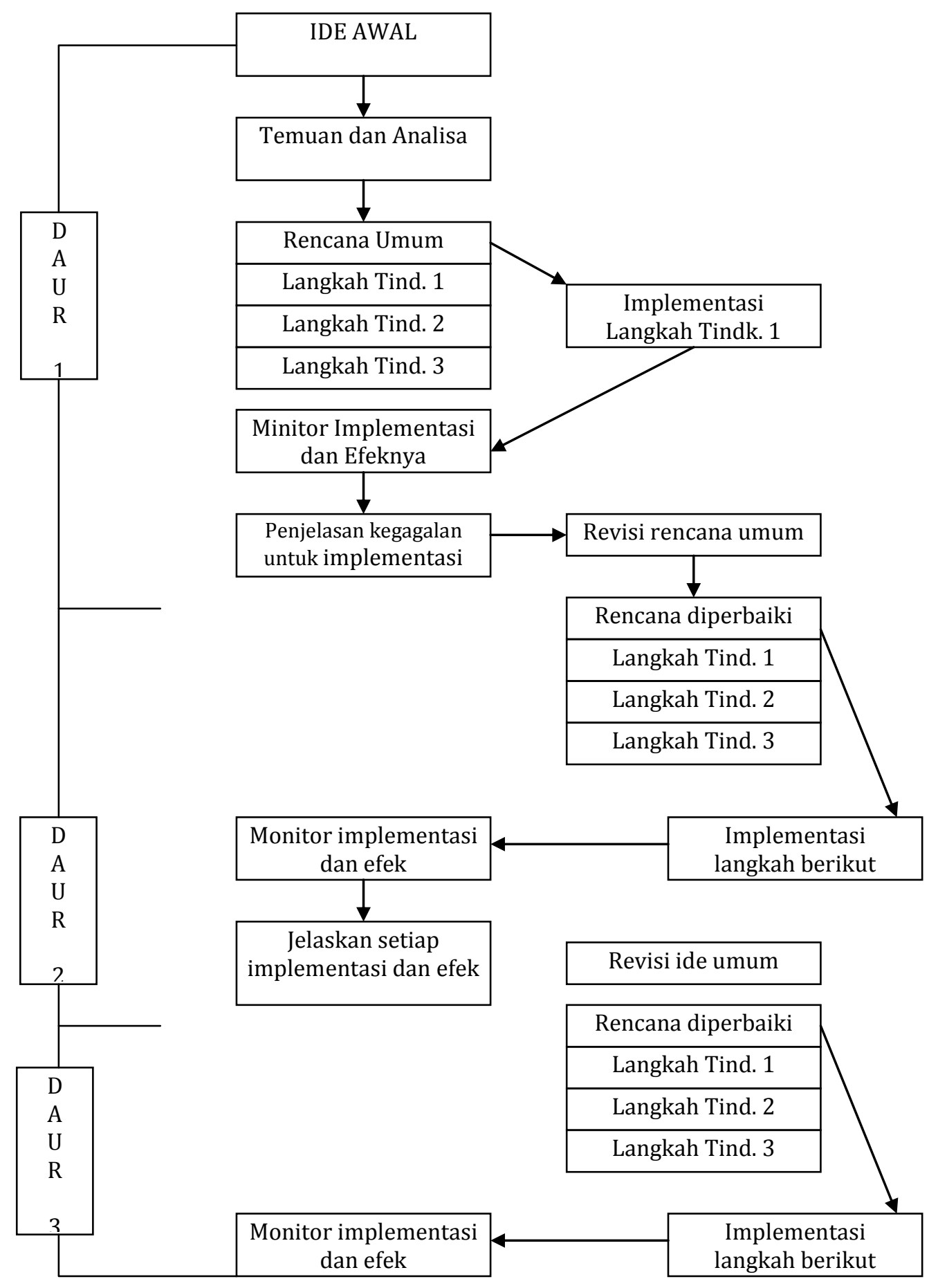

Gambar 1. Rancangan Penelitian Tindakan Model Ebbut (1985) 
Sebagai alur PTK, Ebbut memberi contoh sebagai berikut:Pada daur I dimulai dengan adanya ide awal akibat temuan dan analisis yang telah dilakukan. Setelah ada temuan tersebut dibuatlah perencanaan umum sesuai langkah yang direncanakan baik tindakan 1, tindakan 2 maupun tindakan 3.

Sesudah membuat perencanaan, diimplementasikan dalam tingkat 1, dimonitoring implementasinya serta efeknya kemudian dijelaskan kegagalan-kegagalan yang ada selama implementasinya lalu dibuat revisi umum untuk perencanaan tindakan selanjutnya.

Pada tindakan selanjutnya, perencanaan yang telah dibuat diimplementasikan, terus dimonitor implementasinya serta efek yang ada, dijelaskan setiap langkah implementasinya dan efeknya.

Setelah mengetahui bagaimana hasil dan efeknya, dibuat lagi perencanaan untuk tindakan selanjutnya. Demikian berlanjut sampai menemukan hasil yang sesuai tujuan yang direncanakan.

\section{Hasil dan Pembahasan}

Setiap model pembelajaran memiliki prosedur pelaksanaan sesuai karakteristik dari model pembelajaran itu sendiri. Begitu juga dengan model pembelajaran artikulasi. Huda (2013: 269) menjelaskan bahwa artikulasi merupakan model pembelajaran dengan sistaks: penyampaian kompetensi, sajian materi, bentuk kelompok, berpasangan sebangku, salah satu siswa menyampaikan materi yang baru diterima kepada pasangannya kemudian bergantian, presentasi di depan hasil diskusinya, guru membimbing siswa untuk menyimpulkannya.

Lebih lanjut, berikut langkah-langkah penerapan model artikulasi dalam pembelajaran yang dikemukakan oleh Amri (2013: 213), yaitu:

a. Guru menyampaikan kompetensi yang ingin dicapai.

b. Guru menyajikan materi sebagaimana biasa.

c. Untuk mengetahui daya serap siswa, bentuklah kelompok berpasangan dua orang.

d. Menugaskan salah satu siswa dari pasangan itu menceritakan materi yang baru diterima dari guru dan pasangannya mendengar sambil membuat catatan-catatan kecil, kemudian berganti peran. Begitu juga kelompok lainnya.

e. Menugaskan siswa secara bergiliran/diacak menyampaikan hasil wawancaranya dengan teman pasangannya sampai sebagian siswa sudah menyampaikan hasil wawancaranya.

f. Guru mengulangi/menjelaskan kembali materi yang sekiranya belum dipahami siswa.

g. Kesimpulan/penutup.

Model pembelajaran artikulasi lebih efektif diterapkan dengan menggunakan media gambar. Menurut Tegeh (2008) yang dimaksud media gambar dilihat dari pandangan media grafis adalah gambargambar hasil lukisan tangan, hasil cetakan, dan hasil karya seni fotografi. Penyajian obyek dalam bentuk gambar dapat disajikan melalui bentuk nyata maupun kreasi khayalan belaka sesuia dengan bentuk yang pernah dilihat oleh orang yang menggambarnya.

Kemampuan gambar dapat berbicara banyak dari seribu kata hal ini mempunyai makna bahwa gambar merupakan suatu ilustrasi yang memberikan pengertian dan penjelasan yang amat banyak dan lengkap dibandingkan kita hanya membaca dan memberikan suatu kejelasan pada sebuah masalah karena sifatnya yang lebih konkrit (nyata). Tujuan penggunaan gambar dalam pembelajaran adalah: (1) menerjemahkan symbol verbal, (2) mengkonkritkan dan memperbaiki kesan-kesan yang salah dari ilustrasi lisan. (3) memberikan ilustrasi suatu buku, dan (4) membangkitkan motivasi belajar dan menghidupkan suasana kelas.

Dalam pembelajaran media gambar sangat baik digunakan dan diterapkan dalam proses belajar mengajar sebagai media pembelajaran karena media gambar ini cenderung sangat menarik hati siswa sehingga akan muncul motivasi untuk lebih ingin mengetahui tentang gambar yang dijelaskan dan gurupun dapat menyampaikan materi dengan optimal melalui media gambar tersebut.

Berdasarkan penerapan model pembelajaran artikulasi berbantuan media gambar mendapatkan hasil sebagai berikut.

Data awal yang diperoleh dengan rata-rata 59,68 dengan ketuntasan belajar hanya mencapau $43,75 \%$ menunjukkan bahwa kemampuan anak/siswa dalam mata pelajaran IPA masih sangat rendah mengingat kriteria ketuntasan belajar siswa untuk mata pelajaran ini di SD Negeri 3 Tulikup adalah 70,00. Ini terjadi karena model pembelajaran yang digunakan masih bersifat konvensinal dan guru hanya berceramah dalam menyajikan materi sehingga siswa kesulitan dalam memahami materi. Dengan nilai yang sangat rendah seperti itu maka peneliti mengupayakan untuk dapat meningkatkan prestasi belajar anak/siswa menggunakan model pembelajaran Artikulasi dengan media gambar. Akhirnya dengan penggunaan model pembelajaran Artikulasi dengan media gambar yang benar sesuai teori yang ada, peningkatan rata-rata prestasi belajar anak/siswa pada siklus I dapat diupayakan dan mencapai rata-rata 
69,37. Namun rata-rata tersebut belum maksimal karena hanya 22 siswa memperoleh nilai di atas KKM sedangkan yang lainnya belum mencapai KKM. Sedangkan prosentase ketuntasan belajar mereka baru mencapai 68,75\%. Hal tersebut terjadi akibat penggunaan metode/model pembelajaran Artikulasi dengan media gambar belum maksimal dapat dilakukan disebabkan penerapan model tersebut baru dicobakan sehingga guru masih belum mampu melaksanakannya sesua alur teori yang benar.

Pada siklus ke II perbaikan Prestasi Belajar siswa diupayakan lebih maksimal dengan peneliti membuat perencanaan yang lebih baik, menggunakan alur dan teori model pembelajaran Artikulasi dengan media gambar dengan benar dan lebih maksimal. Peneliti giat memotivasi siswa agar giat belajar, memberi arahan-arahan, menuntun mereka untuk mampu menguasai materi pelajaran pada mata pelajaran IPA lebih optimal. Akhirnya dengan semua upaya tersebut peneliti mampu meningkatkan Prestasi Belajar siswa pada siklus II menjadi rata-rata 78,75 dengan ketuntasan belajar mencapai $100 \%$. Upaya-upaya yang maksimal tersebut menuntun pada suatu keberhasilan bahwa penerapan model pembelajaran Artikulasi dengan media gambar mampu meningkatkan prestasi belajar IPA siswa kelas V SD Negeri 3 Tulikup pada semester I tahun pelajaran 2017/2018.

Hasil penelitian ini sejalan dengan hasil penelitian yang dilakukan oleh Surastini (2013) yang berjudul Penerapan Model Pembelajaran Artikulasi Berbantuan Media Kartu Gambar Untuk Meningkatkan Kemampuan Bahasa. Hasil analisis data menunjukkan bahwa terjadi peningkatan kemampuan menirukan kalimat sederhana dalam pengembangan kemampuan bahasa dengan penerapan model pembelajaran artikulasi pada siklus I sebesar 50,57\% yang berada pada kategori sangat rendah ternyata mengalami peningkatan pada siklus II menjadi 93,83\% tergolong pada kategori sangat tinggi. Jadi terjadi peningkatan perkembangan kemampuan menirukan kalimat sederhana sebesar $46,26 \%$.

\section{Simpulan dan Saran}

Berdasarkan hasil penelitian di atas, dapat disimpulkan bahwa: penerapan model pembelajaran Artikulasi dengan media gambar mampu meningkatkan prestasi belajar IPA siswa kelas V SD Negeri 3 Tulikup pada semester I tahun pelajaran 2017/2018. Semua ini dapat dicapai karena model pembelajaran Artikulasi dengan media gambar sangat efektif diterapkan dalam proses pembelajaran yang mengakibatkan siswa aktif, antusias dan dapat memahami materi yang diajarkan sehingga prestasi belajar siswa menjadi meningkat.

Adapun saran yang dapat disampaikan berdasarkan simpulan penelitian ini adalah sebagai berikut.

1. Bagi Guru kelas khususnya dalam pembelajaran IPA, apabila mau melaksanakan proses pembelajaran penggunaan model yang telah diterapkan ini semestinya menjadi pilihan dari beberapa model yang ada mengingat model ini telah terbukti dapat meningkatkan prestasi belajar siswa.

2. Bagi peneliti lain, walaupun penelitian ini sudah dapat membuktikan efek utama dari model pembelajaran Artikulasi dengan media gambar dalam meningkatkan prestasi belajar, sudah pasti dalam penelitian ini masih ada hal-hal yang belum sempurna dilakukan, oleh karenanya disarankan kepada peneliti lain yang berminat meneliti topik yang sama untuk meneliti bagian-bagian yang tidak sempat diteliti.

3. Bagi pengembang pendidikan, selanjutnya untuk adanya penguatan-penguatan, diharapkan bagi peneliti lain untuk melakukan penelitian lanjutan guna memverifikasi data hasil penelitian ini.

\section{Daftar Rujukan}

Amri, Sofan. 2013. Pengembangan \& Model Pembelajaran Dalam Kurikulum 2013. Jakarta; Prestasi Pustakarya.

Anastasi, Anne. 1976. Psychological Testing. Fifth Edition.New York: Macmillan Publishing Co., Inc.

Arikunto, Suharsimi; Suhardjono; Supardi. 2006. Penelitian Tindakan Kelas. Jakarta: PT Bumi Aksara.

Depdiknas. 2009. Kurikulum Tingkat Satuan Pendidikan. Jakarta: Pusat. Kurikulum, Balitbang Depdiknas.

Ernita, Tiara . 2016. Hubungan Cara Belajar Dengan Prestasi Belajar Siswa Dalam Mata Pelajaran Pkn Pada Siswa Kelas X Sma Negeri 1 Banjarmasin . Jurnal Pendidikan Kewarganegaraan: Volume 6, Nomor 11, Mei 2016.

Huda, Miftahul. 2013. Model-model Pengajaran dan Pembelajaran. Yogyakarta: Pustaka Pelajar. 
Mustain. 2010.Meningkatkan Hasil Belajar Ekonomi melalui ModelPembelajaran Artikulasi pada Siswa Kls X Madrasah Aliyah (MA)Raudhatul Mubtadiin Kundur Kecamatan Tebing Tinggi Barat Kabupaten Kepulauan Meranti (Skripsi). Universitas Islam Riau.Pekanbaru.

Nurkholis. 2013. Pendidikan Dalam Upaya Memajukan Teknologi . Jurnal Kependidikan, Vol. 1 No. 1 Nopember 2013.

Sholichah, Aas Siti . 2018. Teori-Teori Pendidikan Dalam Al-Qur'an . Jurnal Edukasi Islami Jurnal Pendidikan Islam Vol. 07/No.1, April 2018

Surastini, Ni Luh Ari. 2013. Penerapan Model Pembelajaran Artikulasi Berbantuan Media Kartu Gambar Untuk Meningkatkan Kemampuan Bahasa. E-Jurnal Pendidikan Anak Usia Dini Undiksha Volume 1 Nomor 1.

Tegeh, I Made. 2008. Media Pembelajaran. Malang: Program Pascasarjana Universitas Negeri Malang.

Wepe, Sakalus. 2016. Pengaruh Model Pembelajaran Kooperatif Tipe Artikulasi dengan Peta Konsep terhadap Motivasi dan Hasil Belajar IPA-Biologi Siswa (Pokok Bahasan Ekosistem Kelas VII SMPN 11 Jember Tahun Pelajaran 2015/2016) . Jurnal Edukasi Unej 2016

Yuzarion. 2017. Faktor Yang Mempengaruhi Prestasi Belajar Peserta Didik . Ilmu Pendidikan, Volume 2 Nomor 1, Juni 2017 